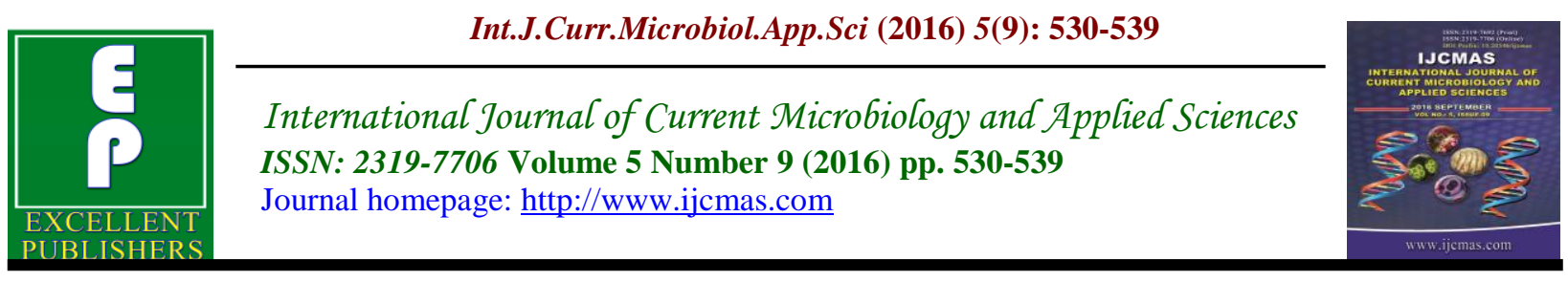

Original Research Article

http://dx.doi.org/10.20546/ijcmas.2016.509.059

\title{
Investigation of the Action of the Anolyte after Different Storage Times on the Gram-negative Bacteria
}

\author{
Teodora P. Popova ${ }^{1}$, Toshka Petrova ${ }^{1}$ and Stoil Karadzhov ${ }^{2}$ \\ ${ }^{1}$ University of Forestry, Faculty of Veterinary Medicine, $10 \mathrm{~K} 1$, \\ Ohridski Blvd., Sofia 1756, Bulgaria \\ ${ }^{2}$ Bulgarian Association of Activated Water, Kutuzov blvd, 39, 1619 Sofia, Bulgaria \\ *Corresponding author
}

\section{Keywords}

Electrochemically, sodium chloride, anolyte,

Pseudomonas aeruginosa, Salmonella enterica, antibacterial activity.

\begin{tabular}{l}
\hline Article Info \\
\hline Accepted: \\
20 August 2016 \\
Available Online: \\
10 September 2016
\end{tabular}

\section{A B S T R A C T}

Studies were carried out to determine the sensitivity of pathogenic Gram-negative bacteria (Salmonella enterica ATCC and Pseudomonas aeruginosa strain №450) to electrochemically activated 3\% aqueous sodium chloride solution (anolyte) in concentrations of $100 \%, 50 \%, 25 \%$ and $12,5 \%$ immediately after preparation (fresh) and after storage at room temperature for 7 days, 21 days and 28 days. As a control was used the disinfectant Virkon $\mathrm{S}$ in concentrations of $1 \%, 0,5 \%, 0,25 \%$ and $0,125 \%$. It was found that the suspension of $P$. aeruginosa with density of $10^{6}$ cells $/ \mathrm{ml}$ was killed after 2 minutes under the influence of all tested concentrations of the fresh anolyte. The same strain in concentration of $10^{8}$ cells $/ \mathrm{ml}$ was killed within 2 minutes by $50 \%$ and $100 \%$ fresh anolyte, but the lower concentrations had such effect after 5 - 10 minutes. The anolyte storaged 7 days had similar action. After 21 and 28 days the anolyte in all tested concentrations had fast bactericidal activity on $P$. aeruginosa in suspension of $10^{6}$ cells $/ \mathrm{ml}$ (in 2 minutes), but in such of $10^{8}$ cells $/ \mathrm{ml}$ single cells remained viable even after 10 minutes. S. enterica in both tested suspensions - of $10^{6}$ and $10^{8}$ cells $/ \mathrm{ml}$ was inactivated within 2 minutes by all examined concentrations not only of the fresh anolyte, but of these stored for 7, 21 and 28 days. Virkon $S$ in all tested concentrations killed within two minutes $P$. aeruginosa and $S$. enterica in both examined densities.

\section{Introduction}

The increasing resistance of pathogenic bacteria to antimicrobial agents is one of the biggest problems today. Bacteria develop resistance not only to antibiotics, but also to disinfectants and fighting them becomes more difficult. On the other hand, the protection of the environment from toxic effects of commonly used disinfectants in medicine, household, industry, agriculture and other fields of human activity is an environmental issue with significant importance. Therefore the demand and application of efficient and at the same time safer from the environmental perspective antimicrobials is very topical. One promising modern approaches in this respect is the electrochemical treatment of water with electricity, which leads to the 
preparation of electrochemically activated aqueous solutions (catholyte and anolyte) having specific physicochemical properties, achieved by changing the electrochemical properties of the water. These activated aqueous solutions - catholyte and anolyte can be used in medicine to treat various bacterial and viral diseases, as well as for disinfection of water (Karadzhov et al., 2014; Ignatov et al., 2015). There are reports for antibacterial and antiviral activity of anolyte. Studies of Atanasov et al., (2014) show that the anolyte does not affect the growth of the cell culture PK-15, but shows a pronounced inhibitory effect on the development of the virus of classical swine fever in it. Gluhchev et al., (2015) also found a significant inhibitory effect of the anolyte on the development of the of Classical swine fever (CSF) virus in cell culture, as well as of Escherichia coli. In the previous our studies (Popova et al., 2016) have experimentally established a high antibacterial activity of the freshly prepared anolyte, which in a concentration of $100 \%$, $50 \%$ and $25 \%$ kills for a short time (2 minutes) suspensions of Gram-negative bacteria: Salmonella enterica, Escherichia coli and Pseudomonas aeruginosa at a concentration of $10^{6}$ cells $/ \mathrm{ml}$ and suspensions of $S$. enterica with concentrations of $10^{8}$ cells $/ \mathrm{ml}$. What is the period of retention of this antibacterial activity is not known, although it is important from a practical point of view.

Therefore in this work we aimed to investigate the effect of anolyte after different intervals of storage at room temperature on highly concentrated suspensions of pathogenic Gram-negative bacteria.

\section{Materials and Methods}

Anolyte (activated water). In the experiments was used anolyte containing $\mathrm{Cl}^{-}$, prepared by electrochemical activation of distillated water with $3 \% \mathrm{NaCl}$, applied in various final concentrations from $12.5 \%$ to $100 \%$. The antibacterial action of the anolyte was tested immediately after preparation (fresh anolyte) and after storage at room temperature for 7 days, 21 days and 28 days.

Control: Virkon $\mathrm{S}$ was used as a control in final concentrations from $1 \%$ to $0,125 \%$.

Microorganisms: In the study were used suspensions with concentrations of $10^{6}$ and $10^{8}$ cells/ml of Pseudomonas aeruginosa № 450 , isolated from an animal with chronic infection and showing multi resistance to antibiotics in vitro. Suspensions with concentrations $10^{6}$ and $10^{8}$ cells $/ \mathrm{ml}$ of Salmonella enterica ATCC were also used. The suspensions were prepared in sterile saline solution by the optical method.

Nutrient media: Culture media from Scharlau - Antisel, Bulgaria were used - agar of Mueller Hinton for the preparation of 24hour cultures of the bacterial strains and Cetrimide agar and Eosin Methylene Blue agar to determine the antimicrobial activity of the tested solutions respectively on $P$. aeruginosa and S. enterica.

Scaffold

Investigation of the antimicrobial activity of anolyte. Twice increasing dilutions of the anolyte were prepared in sterile distilled water and the concentrations obtained were respectively $100 \%$ anolyte, $50 \%, 25 \%$ and $12,5 \%$ in an amounts of $9 \mathrm{ml}$. To each of them was added a suspension of the tested microorganism at a concentration of $10^{9}$ cells $/ \mathrm{ml}$ in an amount of $1 \mathrm{ml}$ at which was achieved a final concentration of $10^{8}$ cells $/ \mathrm{ml}$. The same dilutions of the anolyte with concentrations of $100 \%, 50 \%, 25 \%$ and $12,5 \%$ in quantities of $9 \mathrm{ml}$ were used for the examination of suspensions of the 
microorganisms at a concentration of $10^{6}$ cells $/ \mathrm{ml}$, and for this purpose to each dilution was added by $1 \mathrm{ml}$ of the suspension at a concentration of $10^{7}$ cells $/ \mathrm{ml}$. The following controls were put sterile distilled water (without anolyte) with the same content of the tested bacterial strain, as well as $100 \%$ anolyte without microorganisms.

Study of the antimicrobial activity of Virkon $\mathrm{S}$, used as a control for comparison of the effect of the anolyte. Twice increasing dilutions of Virkon $S$ were prepared in sterile distilled water at concentrations of $1 \%, 0,50 \%, 0,25 \%$, and $0,125 \%$ in an amounts of $9 \mathrm{ml}$. To each of them was added a suspension of the tested microorganism at a concentrations of $10^{9}$ cells $/ \mathrm{ml}$ in an amounts of $1 \mathrm{ml}$ at which were achieve the final concentrations of $10^{8}$ cells $/ \mathrm{ml}$. Pasted were and controls - sterile distilled water (without Virkon S) with the same content of the studied bacterial strain and $1 \%$ Virkon $\mathrm{S}$ without microorganisms. After various time intervals for action of the anolyte and Virkon $S$ (2 min, 5 min and $10 \mathrm{~min}$ ) cultures of each sample were made on Cetrimide agar and Eosin Methylene Blue agar, which were incubated at $37^{\circ} \mathrm{C}$ for $24-48 \mathrm{~h}$ under aerobic conditions. After the cultivation was reported the growth of the test bacteria treated with the test disinfectant, as well as the results of growth of the bacteria on the controls.

\section{Results and Discussion}

The results of the studies with $P$. aeruginosa are presented in Tables 1-4 and Figures 1, 2 and 3. From Table 1 it is seen that the suspension of $P$. aeruginosa 450 with density of $10^{6}$ cells $/ \mathrm{ml}$ was killed after 2 minutes under the influence of all tested concentrations of the fresh anolyte. The same strain in a concentration of $10^{8}$ cells/ml was killed within 2 minutes under the action of $50 \%$ and $100 \%$ fresh anolyte, but with stand for 2 minutes in the solutions with a lower concentration. After 5 and 10 minutes of impact, however, the anolyte in all tested concentrations had a bactericidal effect on this strain in suspensions of density even $10^{8}$ cells $/ \mathrm{ml}$.

From Table 2 and Figure 1 it is clear that the $P$. aeruginosa 450 at concentration of $10^{6}$ cells/ml also was killed after 2 minutes under the effect of all tested concentrations of anolyte storaged 7 days. In a hundred-fold higher concentration tested this strain was killed after 2 minutes under the effect of $100 \%$ anolyte storaged 7 days but lasted for 2 minutes in a solution with its lower concentrations. After 5 and 10 minutes of impact the anolyte storaged 7 days in all tested concentrations also had a bactericidal effect on this strain with density $10^{8}$ cells/ml.

Interesting results showed the anolyte after 21 days of storage. As can be seen from Table 3 and Figure 2, in all tested concentrations it had a bactericidal activity on $P$. aeruginosa 450 with density $10^{6}$ cells $/ \mathrm{ml}$. However, the same strain, tested in suspension with a hundredfold higher density, was affected to a lesser degree by the 21 days storaged anolyte. Even after 10 min effect of undiluted anolyte and of that at concentration of $50 \%$ single cells of $P$. aeruginosa 450 remained viable. This strain when was tested in a high concentration $\left(10^{8}\right.$ cells/ml) showed a higher stability and was not completely killed after 10 minutes exposure even to $100 \%$ anolyte storaged 21 days. The effect of this elder anolyte was significant and greatly reduction of the amount of viable cells was achieved, but single cells remained viable.

The results presented in Table 4 and Figure 
3 show that the freshly prepared solution of Virkon S, used as a control in all the tested concentrations exhibited bactericidal activity on $P$. aeruginosa, whose suspensions in both tested concentrations were killed even within two minutes exposure time.

As it is seen from Table 5, S. enterica ATCC was sensitive to all examined concentrations of the fresh anolyte even in suspension with the highest density of $10^{8}$ cells/ml tested.

S. enterica ATCC, however, showed a high sensitivity to all tested concentrations $(12,5 \%$ to $100 \%)$ of the anolyte stored for 7 days (Table 6) and even for 21 days (Table 7).

As can be seen from Table 7 and Figure 4, this long stored anolyte inactivated suspensions of this strain of $S$. enterica even at concentration of $10^{8}$ cells $/ \mathrm{ml}$ within 2 minutes.

The data in Table 8 show that the 28 days stored anolyte in all tested concentrations (from $12,5 \%$ to $100 \%$ ) had a bactericidal effect on the suspensions at a concentration of $10^{6}$ cells $/ \mathrm{ml}$ of $P$. aeruginosa 450 and of S. enterica even within 2 min exposure time.

The results presented in Table 9 show that the solutions of Virkon S, used as a control, in all the tested concentrations exhibited bactericidal activity on S. enterica ATCC, whose suspensions in both tested concentrations were killed even within two minutes exposure time.

From the presented results it is clear that not only the fresh anolyte, but also that after storage for 1 to 3 and even 4 weeks exhibit high bactericidal activity against pathogenic Gram-negative bacteria such as Pseudomonas aeruginosa and Salmonella enterica, which are distinguished by particularly high resistance to disinfectants. Especially encouraging are the data obtained for Salmonella enterica. It appears to be very sensitive to all concentrations of the anolyte even after 4 weeks of its storage. In Pseudomonas aeruginosa the results depend on the density of the tested suspensions, as well as on the time of storage of the anolyte.

Table.1 Growth (quantity of colonies) of $P$. aeruginosa 450 at concentrations of 106 cells $/ \mathrm{ml}$ and 108 cells/ml after various intervals of exposure of fresh anolyte, applied in different concentrations

\begin{tabular}{lllllll}
\hline $\begin{array}{l}\text { Concentration of } \\
\text { the anolyte in \% }\end{array}$ & \multicolumn{5}{c}{ Exposure time - min } \\
\cline { 2 - 7 } & \multicolumn{7}{c}{$\mathbf{2}$} & & $\mathbf{5}$ & & $\mathbf{1 0}$ \\
\cline { 2 - 7 } & $\mathbf{1 0}^{\mathbf{6}}$ & $\mathbf{1 0}^{\mathbf{8}}$ & $\mathbf{1 0}^{\mathbf{6}}$ & $\mathbf{1 0}^{\mathbf{8}}$ & $\mathbf{1 0}^{\mathbf{6}}$ & $\mathbf{1 0}^{\mathbf{8}}$ \\
\hline $\mathbf{1 0 0}$ & 0 & 0 & 0 & 0 & 0 & 0 \\
$\mathbf{5 0}$ & 0 & 0 & 0 & 0 & 0 & 0 \\
$\mathbf{2 5}$ & 0 & Single & 0 & 0 & 0 & 0 \\
$\mathbf{1 2 , 5}$ & 0 & Single & 0 & 0 & 0 & 0 \\
$\begin{array}{l}\text { Control (bacteria } \\
\text { without anolyte) }\end{array}$ & many & Many & many & Many & many & many \\
$\begin{array}{l}\text { Control (anolyte } \\
\text { without bacteria) }\end{array}$ & 0 & 0 & 0 & 0 & 0 & 0 \\
\hline
\end{tabular}


Table.2 Growth (quantity of colonies) of $P$. aeruginosa 450 at concentrations of 106 cells $/ \mathrm{ml}$ and 108 cells $/ \mathrm{ml}$ after various time intervals of exposure to the anolyte storaged 7 days, applied in different concentrations

\begin{tabular}{|c|c|c|c|c|c|c|}
\hline \multirow{3}{*}{$\begin{array}{l}\text { Concentration of } \\
\text { the anolyte in \% }\end{array}$} & \multicolumn{6}{|c|}{ Exposure time - min } \\
\hline & \multicolumn{2}{|c|}{2} & \multicolumn{2}{|c|}{5} & \multicolumn{2}{|c|}{$\mathbf{1 0}$} \\
\hline & $10^{6}$ & $10^{8}$ & $10^{6}$ & $10^{8}$ & $10^{6}$ & $10^{8}$ \\
\hline 100 & 0 & 0 & 0 & 0 & 0 & 0 \\
\hline 50 & 0 & single & 0 & 0 & 0 & 0 \\
\hline 25 & 0 & single & 0 & 0 & 0 & 0 \\
\hline 12,5 & 0 & single & 0 & 0 & 0 & 0 \\
\hline $\begin{array}{l}\text { Control (bacteria } \\
\text { without anolyte) }\end{array}$ & many & many & many & Many & many & many \\
\hline $\begin{array}{l}\text { Control (anolyte } \\
\text { without bacteria) }\end{array}$ & 0 & 0 & 0 & 0 & 0 & 0 \\
\hline
\end{tabular}

Table.3 Growth (number of colonies) of $P$. aeruginosa 450 at concentrations of 106 cells $/ \mathrm{ml}$ and 108 cells/ml after various intervals of exposure to the anolyte, storaged 21 days, applied at various concentrations.

\begin{tabular}{lllllll}
\hline Concentration of the & \multicolumn{6}{c}{ Exposure time - min } \\
\cline { 2 - 7 } analyte in\% & \multicolumn{7}{c}{$\mathbf{2}$} & $\mathbf{1 0}^{\mathbf{8}}$ & $\mathbf{1 0}^{\mathbf{6}}$ & $\mathbf{1 0}$ & $\mathbf{1 0}^{\mathbf{6}}$ & $\mathbf{1 0}$ \\
\cline { 2 - 7 } & $\mathbf{1 0}^{\mathbf{8}}$ & 1 & 0 & single & 0 & 1 \\
\hline $\mathbf{1 0 0}$ & 0 & 12 & 0 & 30 & 0 & single. \\
$\mathbf{5 0}$ & 0 & 30 & 0 & 36 & 0 & many \\
$\mathbf{2 5}$ & 0 & Many & 0 & Many & 0 & many \\
$\mathbf{1 2 , 5}$ & many & Many & many & Many & many & many \\
$\begin{array}{l}\text { Control (bacteria } \\
\text { without anolyte) }\end{array}$ & 0 & 0 & 0 & 0 & 0 & 0 \\
$\begin{array}{l}\text { Control (anolyte } \\
\text { without bacteria) }\end{array}$ & 0 & & & & & \\
\hline
\end{tabular}

Table.4 Growth (number of colonies) of $P$. aeruginosa 450 at concentrations of 106 cells $/ \mathrm{ml}$ and 108 cells/ml after different intervals of impact of Virkon $\mathrm{S}$ at various concentrations

\begin{tabular}{llllllll}
\hline Concentration of & \multicolumn{7}{c}{ Exposure time - min } \\
\cline { 2 - 7 } \multicolumn{1}{l}{ Virkon S in \% } & \multicolumn{2}{c}{$\mathbf{2}$} & \multicolumn{3}{c}{$\mathbf{5}$} & $\mathbf{1 0}$ \\
\cline { 2 - 7 } & $\mathbf{1 0}^{\mathbf{6}}$ & $\mathbf{1 0}^{\mathbf{8}}$ & $\mathbf{1 0}^{\mathbf{6}}$ & $\mathbf{1 0}^{\mathbf{8}}$ & $\mathbf{1 0}^{\mathbf{6}}$ & $\mathbf{1 0}^{\mathbf{8}}$ \\
\hline $\mathbf{1}$ & 0 & 0 & 0 & 0 & 0 & 0 \\
$\mathbf{0 , 5}$ & 0 & 0 & 0 & 0 & 0 & 0 \\
$\mathbf{0 , 2 5}$ & 0 & 0 & 0 & 0 & 0 & 0 \\
$\mathbf{0 , 1 2 5}$ & 0 & 0 & 0 & 0 & 0 & 0 \\
$\begin{array}{l}\text { Control (bacteria } \\
\text { without Virkon S) }\end{array}$ & many & many & many & Many & many & many \\
$\begin{array}{l}\text { Control (Virkon S } \\
\text { without bacteria) }\end{array}$ & 0 & 0 & 0 & 0 & 0 & 0 \\
\hline
\end{tabular}


Table.5 Growth (number of colonies) of S. enterica ATCC at concentrations of $106 \mathrm{cells} / \mathrm{ml}$ and 108 cells/ml after various intervals of impact of fresh anolyte applied in different concentrations

\begin{tabular}{|c|c|c|c|c|c|c|}
\hline \multirow{3}{*}{$\begin{array}{l}\text { Concentration of } \\
\text { the anolyte in \% }\end{array}$} & \multicolumn{6}{|c|}{ Exposure time - min } \\
\hline & \multicolumn{2}{|c|}{2} & \multicolumn{2}{|c|}{5} & \multicolumn{2}{|c|}{10} \\
\hline & $10^{6}$ & $10^{8}$ & $10^{6}$ & $10^{8}$ & $10^{6}$ & $10^{8}$ \\
\hline 100 & 0 & 0 & 0 & 0 & 0 & 0 \\
\hline 50 & 0 & 0 & 0 & 0 & 0 & 0 \\
\hline 25 & 0 & 0 & 0 & 0 & 0 & 0 \\
\hline 12,5 & 0 & 0 & 0 & 0 & 0 & 0 \\
\hline $\begin{array}{l}\text { Control (bacteria } \\
\text { without anolyte) }\end{array}$ & many & many & many & many & many & many \\
\hline $\begin{array}{l}\text { Control (anolyte } \\
\text { without bacteria) }\end{array}$ & 0 & 0 & 0 & 0 & 0 & 0 \\
\hline
\end{tabular}

Table.6 Growth (number of colonies) of S. enterica ATCC at concentrations of 106 cells $/ \mathrm{ml}$ and 108 cells $/ \mathrm{ml}$ after various intervals of exposure to the anolyte storaged 7 days and administered at various concentrations.

\begin{tabular}{|c|c|c|c|c|c|c|}
\hline \multirow{3}{*}{$\begin{array}{l}\text { Concentration of } \\
\text { the anolyte in \% }\end{array}$} & \multicolumn{6}{|c|}{ Exposure time - min } \\
\hline & \multicolumn{2}{|c|}{2} & \multicolumn{2}{|c|}{5} & \multicolumn{2}{|c|}{10} \\
\hline & $10^{6}$ & $10^{8}$ & $10^{6}$ & $10^{8}$ & $10^{6}$ & $10^{8}$ \\
\hline 100 & 0 & 0 & 0 & 0 & 0 & 0 \\
\hline 50 & 0 & 0 & 0 & 0 & 0 & 0 \\
\hline 25 & 0 & 0 & 0 & 0 & 0 & 0 \\
\hline 12,5 & 0 & 0 & 0 & 0 & 0 & 0 \\
\hline $\begin{array}{l}\text { Control (bacteria } \\
\text { without anolyte) }\end{array}$ & Many & many & many & Many & many & many \\
\hline $\begin{array}{l}\text { Control (anolyte } \\
\text { without bacteria) }\end{array}$ & 0 & 0 & 0 & 0 & 0 & 0 \\
\hline
\end{tabular}

Table.7 Growth (number of colonies) of S. enterica ATCC at concentrations of 106 cells $/ \mathrm{ml}$ and 108 cells/ml after various intervals of exposure to the anolyte, storaged 21 days, applied at various concentrations

\begin{tabular}{lllllll}
\hline \multirow{2}{*}{$\begin{array}{l}\text { Concentration of } \\
\text { the anolyte in \% }\end{array}$} & \multicolumn{6}{c}{ Exposure time - min } \\
\cline { 2 - 7 } & \multicolumn{7}{c}{$\mathbf{2}$} & $\mathbf{1 0}^{\mathbf{8}}$ & $\mathbf{1 0}^{\mathbf{6}}$ & $\mathbf{1 0}^{\mathbf{8}}$ & $\mathbf{1 0}^{\mathbf{6}}$ & $\mathbf{1 0}$ \\
\hline $\mathbf{1 0 0}$ & 0 & 0 & 0 & 0 & 0 & 0 \\
$\mathbf{5 0}$ & 0 & 0 & 0 & 0 & 0 & 0 \\
$\mathbf{2 5}$ & 0 & 0 & 0 & 0 & 0 & 0 \\
$\mathbf{1 2 , 5}$ & 0 & 0 & 0 & 0 & 0 & 0 \\
$\begin{array}{l}\text { Control (bacteria } \\
\text { without anolyte) }\end{array}$ & many & many & many & many & many & many \\
$\begin{array}{l}\text { Control (anolyte } \\
\text { without bacteria) }\end{array}$ & 0 & 0 & 0 & 0 & 0 & 0 \\
\hline
\end{tabular}


Table.8 Growth (number of colonies) of P. aeruginosa 450 and of S. enterica ATCC at concentrations of 106 cells $/ \mathrm{ml}$ after various intervals of exposure to the anolyte, storaged 28 days and applied at different concentrations

\begin{tabular}{lllllll}
\hline \multirow{2}{*}{$\begin{array}{l}\text { Concentration of } \\
\text { the anolyte in \% }\end{array}$} & \multicolumn{6}{c}{ Exposure time - min } \\
\cline { 2 - 7 } & $\begin{array}{l}\text { P. aeru- } \\
\text { ginosa }\end{array}$ & $\begin{array}{l}\text { S. ente- } \\
\text { rica }\end{array}$ & $\begin{array}{l}\text { P. aeru- } \\
\text { ginosa }\end{array}$ & $\begin{array}{l}\text { S. ente- } \\
\text { rica }\end{array}$ & $\begin{array}{l}\text { P. aeru- } \\
\text { ginosa }\end{array}$ & $\begin{array}{l}\text { S. } \text { ente- } \\
\text { rica }\end{array}$ \\
\hline $\mathbf{1 0 0}$ & 0 & 0 & 0 & 0 & 0 & 0 \\
$\mathbf{5 0}$ & 0 & 0 & 0 & 0 & 0 & 0 \\
$\mathbf{2 5}$ & 0 & 0 & 0 & 0 & 0 & 0 \\
$\mathbf{1 2 , 5}$ & 0 & 0 & 0 & 0 & 0 & 0 \\
$\begin{array}{l}\text { Control (bacteria } \\
\text { without anolyte) }\end{array}$ & many & Many & many & many & many & many \\
$\begin{array}{l}\text { Control (anolyte } \\
\text { without bacteria) }\end{array}$ & 0 & 0 & 0 & 0 & 0 & 0 \\
\hline
\end{tabular}

Table.9 Growth (number of colonies) of S. enterica ATCC at concentrations of $106 \mathrm{cells} / \mathrm{ml}$ and 108 cells/ml after different intervals of impact of Virkon S, applied at various concentrations

\begin{tabular}{llllllll}
\hline $\begin{array}{l}\text { Concentration of } \\
\text { the Virkon S in \% }\end{array}$ & \multicolumn{7}{c}{ Exposure time - min } \\
\cline { 2 - 8 } & \multicolumn{1}{c}{$\mathbf{1 0}^{\mathbf{6}}$} & $\mathbf{1 0}^{\mathbf{8}}$ & $\mathbf{1 0}^{\mathbf{6}}$ & $\mathbf{1 0}^{\mathbf{8}}$ & $\mathbf{1 0}^{\mathbf{6}}$ & $\mathbf{1 0}^{\mathbf{8}}$ \\
\hline $\mathbf{1}$ & 0 & 0 & 0 & 0 & 0 & 0 \\
$\mathbf{0 , 5}$ & 0 & 0 & 0 & 0 & 0 & 0 \\
$\mathbf{0 , 2 5}$ & 0 & 0 & 0 & 0 & 0 & 0 \\
$\mathbf{0 , 1 2 5}$ & 0 & 0 & 0 & 0 & 0 & 0 \\
$\begin{array}{l}\text { Control (bacteria } \\
\text { without Virkon S) }\end{array}$ & many & many & many & Many & many & many \\
$\begin{array}{l}\text { Control (Virkon S } \\
\text { without bacteria) }\end{array}$ & 0 & 0 & 0 & 0 & 0 & 0 \\
\hline
\end{tabular}

Fig.1 Growth of $P$. aeruginosa 450 after impact of the anolyte storaged 7 days, applied in various concentrations (100\%, 50\%, 25\% and 12.5\%) with a duration of 2 min (left), 5 min (in the middle) and $10 \mathrm{~min}$ (right).

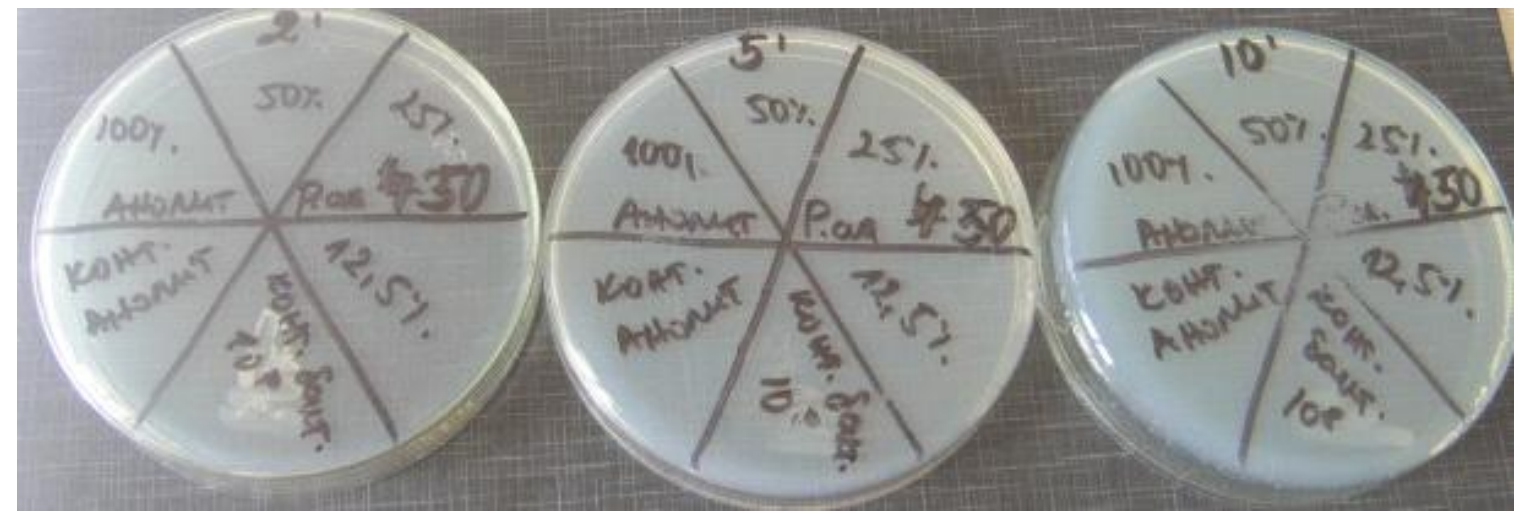


Fig.2 Growth of $P$. aeruginosa 450 after impact of anolyte storaged 21 days after its preparation, applied in different concentrations $(100 \%, 50 \%, 25 \%$ and $12.5 \%)$ with a duration of 2 min (left), $5 \mathrm{~min}$ (in the middle) and $10 \mathrm{~min}$ (right) on suspensions of concentration of $106 \mathrm{cells} / \mathrm{ml}$ (above) and 108 cells $/ \mathrm{ml}$ (below).
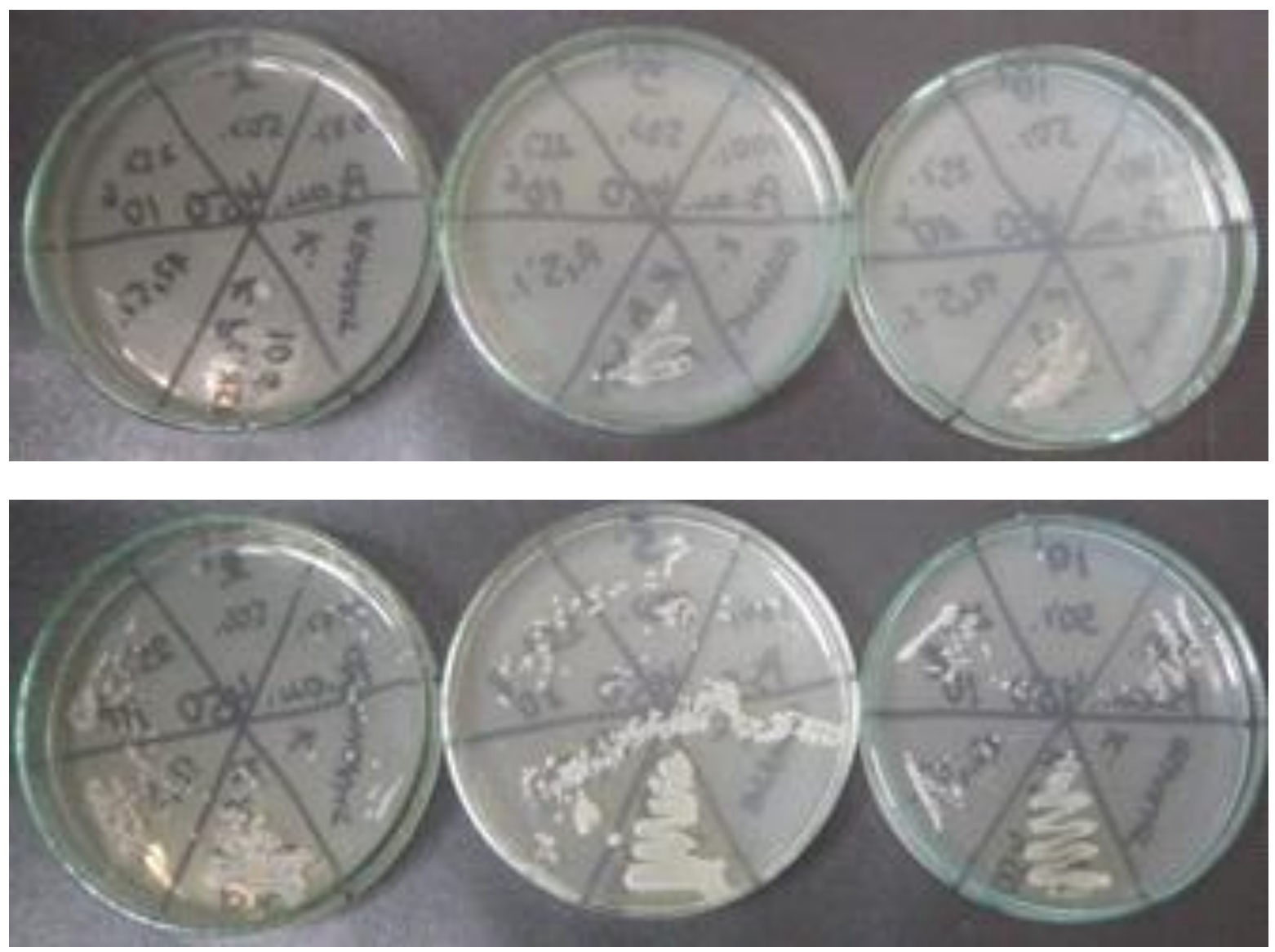

Fig.3 Growth of $P$. aeruginosa 450 after impact of Virkon $\mathrm{S}$ in various concentrations (1\%, $0.50 \%, 0,25 \%$ and $0,125 \%$ ) with duration of $2 \mathrm{~min}$ (left), $5 \mathrm{~min}$ (in the middle) and $10 \mathrm{~min}$ (right).

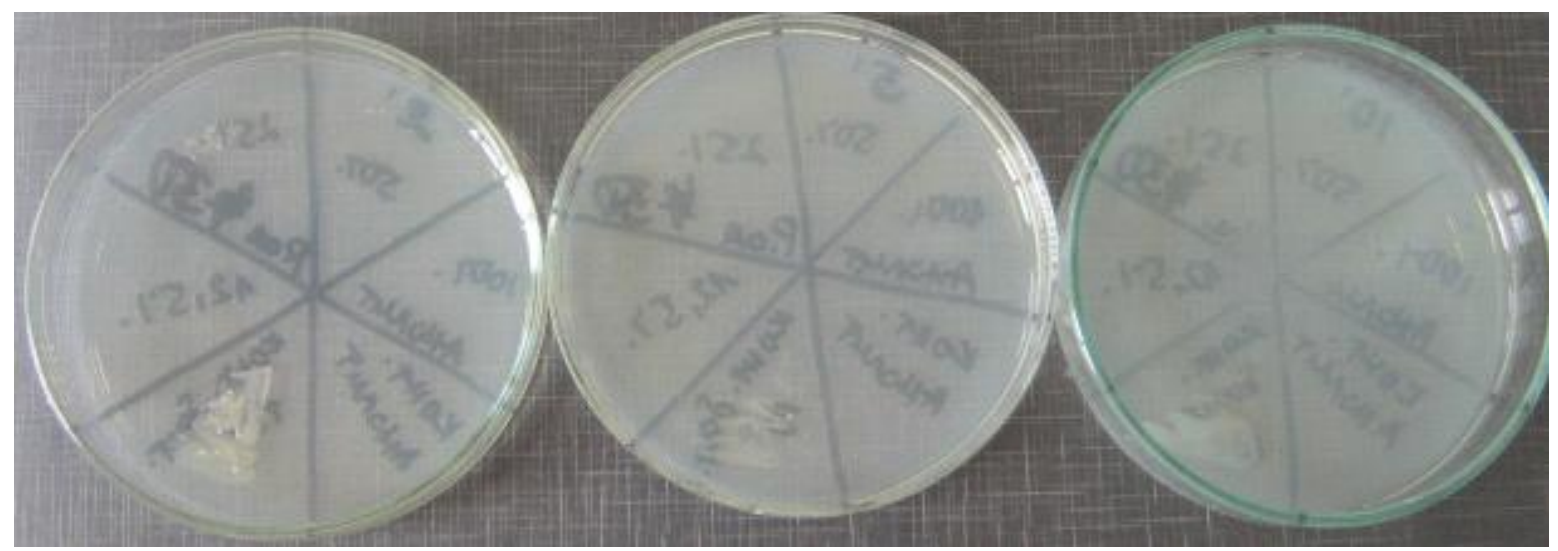


Fig.4 Growth of S. enterica at concentration of 108 cells $/ \mathrm{ml}$ after impact of anolyte storaged 21 days after its preparation, applied in different concentrations $(100 \%, 50 \%, 25 \%$ and $12,5 \%)$ with a duration of $2 \mathrm{~min}$ (left), $5 \mathrm{~min}$ (in the middle) and $10 \mathrm{~min}$ (right). Colonies are visible only in the field of control with bacteria, without anolyte (below sectors)

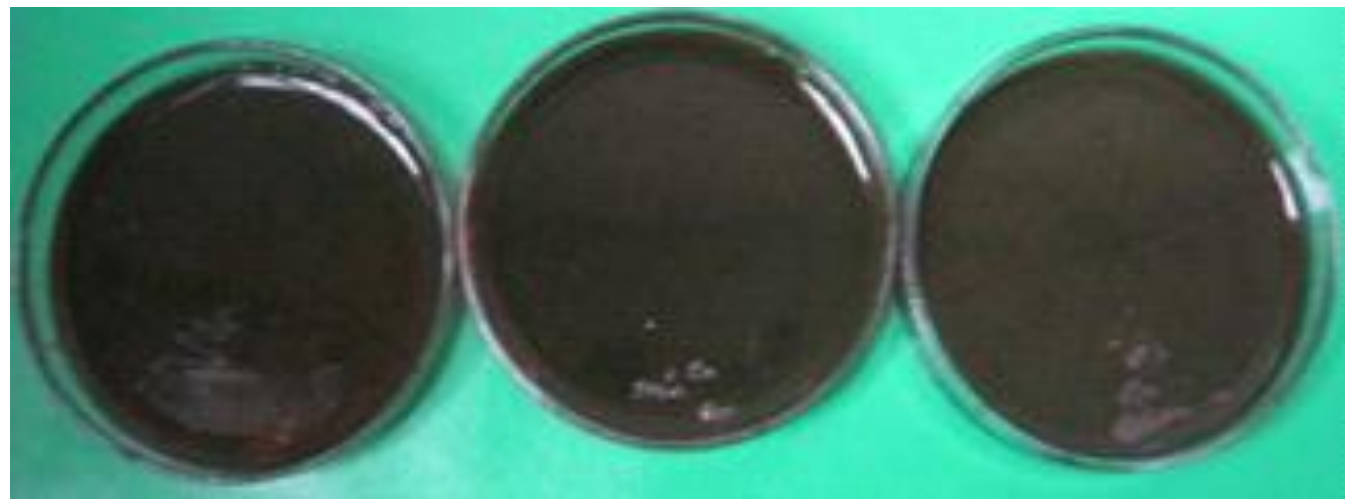

Comparatively less sensitivity to the longterm storaged at room temperature anolyte, as well as when the tested strains of Pseudomonas aeruginosa are in suspensions with a high density $\left(10^{8}\right.$ cells $\left./ \mathrm{ml}\right)$, probably is due to the presence of additional protective polysaccharide coat of the cells glycocalyx.

After 7-day of storage the effect of anolyte is completely analogous to the freshly prepared one and it can be used with the same success for fast and safe disinfection of materials containing high concentrations (up to $10^{8}$ cells $/ \mathrm{ml}$ ) even of the most resistant to chemical effects Gram-negative bacteria in an aqueous medium such as $P$. aeruginosa and S. enterica. After this period of storage the effect of the anolyte with respect to these microorganisms is retained even up to 4 weeks after its preparation for the salmonellas, and for $P$. aeruginosa it is effective for materials, which contain not more than $10^{6}$ cells $/ \mathrm{ml}$ in an aqueous medium. At higher concentrations of bacteria of this type the quantity of viable cells is significantly reduced within 10 minutes exposure time, but some of them remain viable.

These data categorically show that anolyte is sure disinfectant with rapid bactericidal effect, which fully retains its high bactericidal activity within period of time for three weeks. After this period it can also be used successfully for the rapid (within 25 minutes) disinfection of materials containing Gram-negative bacteria in an aqueous medium at concentration up to $10^{6}$ cells $/ \mathrm{ml}$. For materials with a higher concentration of bacterial cells it is necessary a more prolonged exposure time of undiluted anolyte, and most sure is to be used a fresh anolyte or the one that has been stored no longer than seven days.

The active ingredient of anolyte is hypochlorous acid $(\mathrm{HClO})$, which normally occurs in eukaryotic organisms and is involved in the reactions of the immune response (killing pathogens during phagocytosis). The surface activity of hypochlorous acid (in sufficient concentrations) is based on the destruction of the cell membrane of the microbial cells (Nixall, 2015). Obviously, this acid is kept in sufficient concentrations in the anolyte for the researched by us 4-week period.

The high efficiency of the anolyte with respect to some of the most resistant Gramnegative bacteria such as $P$. aeruginosa and $S$. enterica is an indicator of similar 
performance with respect to the most of the others species of microorganisms of this group. However, further studies are needed to identify the spectrum of the effectiveness of the anolyte, as well as the timing of its bactericidal action to materials with different concentrations of microorganisms.

In conclusion, the anolyte is sure disinfectant with rapid bactericidal effect, that immediately after its preparation, as well as after storage for 1 week exhibits high bactericidal activity against pathogenic Gram-negative bacteria of the species which are distinguished by particularly high resistance to disinfectants such as Pseudomonas aeruginosa and Salmonella enterica at significant cell density (up to $10^{8}$ cells $/ \mathrm{ml}$ ). The effect of the anolyte after 3 weeks of storage at room temperature is completely analogous to the freshly prepared one in respect of S. enterica, and for $P$. aeruginosa the effect is maintained in suspension with a cell density of up to $10^{6}$ cells $/ \mathrm{ml}$. Anolyte after storage at room temperature for 4 weeks fully retains its high bactericidal activity against $S$, enterica with a high density of cells (up to $10^{8}$ cells $/ \mathrm{ml}$ ). For $P$. aeruginosa, however, the results with the use of stored four weeks anolyte depend on the density of the tested suspensions.

\section{References}

Atanasov, A., S. Karadzhov, E. Ivanova, O. Mosin, and Ignatov, I. 2014. Study of the effects of electrochemical aqueous sodium chloride solution (Anolyte) on the virus of Classical swine fever. Mathematical models of anolyte and catolyte as types of water. J. Med. Physiol. Biophysics, 4: 1-26, www.iiste.org.

Gluhchev, G, I. Ignatov, S. Karadzhov, G. Miloshev, N. Ivanov, and Mosin, O. 2015. Studying the Antimicrobial and antiviral effects of electrochemically activated $\mathrm{NaCl}$ solutions of anolyte and catholyte on a strain of E. coli DH5 and Classical swine fever (CSF) virus. Euro. J. Med., 9(3): 124-138. doi: 10.13187/ejm. 2015.9.124

Ignatov, I., G. Gluhchev, S. Karadzhov, G. Miloshev, N. Ivanov, and Mosin, O. 2015. Preparation of electrochemically activated water solutions (Catholyte/Anolyte) and studying their physical-chemical properties. J. Med. Physiol. Biophysics, 11: 1-21, www.iiste.org, ISSN 2422-8427 (Online).

Karadzhov, S., A. Atanasov, E. Ivanova, O. Mosin, and Ignatov, I. 2014. Mathematical models of electrochemical aqueous sodium chloride solutions (Anolyte and Catholyte) as types of water. Study of the effects of anolyte on the virus of Classical swine fever. $J$. Health, Med. Nursing An Open Access J., 5: 30-55, www.iiste.org.

Nixall, 2015. http://www.nixall.com/ pages/anolyte-water.

Popova, T.P., T. Petrova, and Karadzhov, S. 2016. Investigation of the biocidal effect of electrochemically activated aqueous sodium shloride solution on Gramnegative pathogenic bacteria. Int. J. Curr. Microbiol. App. Sci., 5(1): 624632, doi: http://dx.doi.org/ 10.20546/ijcmas.2016.501.063

\section{How to cite this article:}

Teodora P. Popova, Toshka Petrova and Stoil Karadzhov. 2016. Investigation of the Action of the Anolyte after Different Storage Times on the Gram-negative Bacteria. Int.J.Curr.Microbiol.App.Sci. 5(9): 530-539. doi: http://dx.doi.org/10.20546/ijcmas.2016.509.059 